\title{
Problematic Mobile Phone and Internet Use: A Comparative Study between Saudi and Egyptian Female Adolescents
}

Dalia E. Desouky ${ }^{1,2}$

${ }^{1}$ Department of Family and Community Medicine, College of Medicine, Taif University, Saudi Arabia

${ }^{2}$ Department of Public Health and Community Medicine, Faculty of Medicine, Menoufia University, Egypt

\section{Abstract:}

Background: Adolescents are vulnerable to both mobile and internet addiction. In Arab countries studies on both types of addiction are scarce. Objectives: This study aimed at comparing the prevalence of problematic mobile and internet use among Egyptian and Saudi adolescent females. Methods: A cross sectional study which included 538 Saudi and 802 Egyptian adolescent female students. A questionnaire was used to collect data about patterns of mobile phone and internet use. Young Internet Addiction Test (YIAT) and the Mobile Phone Addiction Scale (MPAI) were also used. Results: Saudi students showed higher rates of mobile $(11.7 \%)$ and internet addiction $(5.8 \%)$ compared to Egyptian students $(6.1 \%$ \& $1.6 \%$ respectively). They also had higher number of calls, longer time of internet use and more frequent internet use per week. A significant weak positive correlation was found between YIAT scores and MPAI scores. Conclusion: This study indicated the need for future studies to address the related risk factors of both problems among adolescents in both countries. Key wards: Problematic, mobile, internet, Saudi, Egyptian, adolescents.

Introduction: Problematic mobile phone use (PMPU) is a behavior which makes the individual unable to regulate his mobile phone use, leading to dependence, social and behavioral problems. ${ }^{(1)}$ Problematic internet use (PIU) is the uncontrollable use of the internet which is markedly distressing and resulting in social, occupational or financial difficulties. ${ }^{(2)}$ Mobile phones became an integral part of adolescent's lives. ${ }^{(3)}$ It provides identity and prestige among peers ${ }^{(4)}$, and offers recent technological innovations in which adolescents are highly interested. ${ }^{(5)}$ That is why they are a vulnerable group to mobile phone addiction.

Adolescents were also found to be vulnerable to internet addiction and to the psychological and sociological problems related to it. ${ }^{(6)}$ Internet and mobile phone addiction are closely related, as studies have shown a significant correlation between the two types of addiction, which was explained by sharing parallel lifestyles in both types of addicts. ${ }^{(7)}$ Excessive mobile users experience depressive symptoms, difficulty in expression of emotion, higher interpersonal anxiety and lower self-esteem. ${ }^{(8)}$ Internet addiction was found to be correlated with depression, anxiety, stress. ${ }^{(9)}$

Previous studies in Western and Eastern societies reported a wide range prevalence of internet addiction among adolescents (from $1.4 \%$ up to $17.9 \%)^{(6,10)}$, and a prevalence of mobile phone addiction (from 0 up to $38 \%$ ). ${ }^{(1)}$ There were 16.4 million internet users in Saudi Arabia in $2013^{(11)}$, and regarding mobile phone use, Saudi Arabia has the largest number of 
mobile phone users worldwide. ${ }^{(12)}$ In Egypt, according to the Ministry of Communications and Information Technology report in 2013, the number of internet users reached 30 million, with young people constituting more than $80 \%$ of the internet café clients. ${ }^{(13)}$ The number of Egyptian mobile phone users reached 92 million in 2013. ${ }^{(14)}$

In Saudi Arabia, only two studies were carried out to address the physical adverse effects of mobile phone use. ${ }^{(15,16)}$ Regarding internet addiction, a previous Saudi study carried out on secondary school students found a prevalence of $5.3 \%{ }^{(17)}$ In Egypt, the same physical adverse effects of mobile phone use were addressed in a previous study. ${ }^{(18)}$ And according to internet addiction, two studies were done on adolescents, one found a prevalence of $2.6 \%$ of PIU ${ }^{(19)}$, and the other found a prevalence of $0.8 \%{ }^{(20)}$ Studies on PIU and PMPU in Arab countries are scarce. The present study aimed at assessing the prevalence of PIU and PMPU among adolescent females in two Arab countries, Egypt and Saudi Arabia.

Methods: A cross-sectional study was carried out from January to April 2018. The study included adolescent female students from Egypt and Saudi Arabia. For the Egyptian sample, a multistage sampling was done, where the secondary schools in Menoufia Governorate was the sampling frame. Two private and public schools were randomly selected. Only female classes in both schools were considered. There were 12 female classes for the 3 grades of the public school, and 9 female classes for the 3 grades of the private school. The total number of female students in both schools was 839, and after exclusion of the non-respondents, the response rate was $95.5 \%$ and 802 students constituted the Egyptian sample.

For the Saudi sample, the same sampling methodology was followed, where the secondary schools in Al-Taif city was the sampling frame. From the 12 female secondary schools in the city, two schools (one public and one private) were selected randomly. In each school, there were 9 classes for the 3 grades. The total number of students in the 18 classes in both schools was 585 students. Students who refused sharing in the study or were absent during the study days were excluded. The response rate was $91.9 \%$, with total sample of 538 Saudi female students.

Ethical Considerations: Official approvals were obtained from the ethics committee of scientific research of Al-Taif University, and from the school headmasters in KSA. 
Approvals were obtained also from the ethics committee of the faculty of medicine of Menoufia University. The aim of the study was explained to schools managers and students, and verbal consents were obtained from the respondent students before sharing in the study.

Study instrument: Students were asked to complete a questionnaire to collect data about (a) age and educational grade, (b) Pattern of mobile phone use: duration of having a mobile phone, mobile type, and number of daily calls (c) Pattern of internet use: time spent on-line per day and frequency of internet use per week. Two scales were used to collect data about internet and mobile phone addiction.

The Arabic version of the Young internet addiction test (YIAT) was used. It was validated in a previous Lebanon study. ${ }^{(21)}$ It is a 20-items questionnaire where students were asked to indicate their answer for each item on a Likert scale ranging from 1 to 5, with 1 indicating "not at all"' and 5 indicating "always". The total scores ranged from 20-100. Students were classified according to their scores into: internet addicts (score from 70 to 100), potential internet addicts (score from 40 to 69), and non-addicts with a score less than 40 . The same cut offs were used to measures different levels of internet addiction in other studies. ${ }^{(22)}$ A high reliability estimate of YIAT was reported with a Cronbach's alpha above 0.80 in the previous studies. ${ }^{(23)}$

Similarly, the mobile phone addiction scale (MPAI) was used. It is a 17 items scale where one answer for every item was allocated on a Likert scale ranging from 0 to 4. The internal reliability of the MPAI was reported in previous studies with Cronbach's alpha above $0.90 .{ }^{(24)}$ The cut-off point score for MPAI scale was 51, where students who obtained scores higher than 51 were considered as mobile addicts. ${ }^{(25)}$ According to the literature review, no study was carried out in any of the Arabic countries to assess mobile phone addiction, so there was not any Arabic validated version of any mobile phone addiction scale. In the present study the mobile phone addiction scale was translated to Arabic by a health care professional and an expert in the field of translation fluent in both Arabic and English.

The Arabic form was back translated into English by another two experts fluent in the same languages who were blinded to the original English version of the scale. Then, the back translated version was compared with the original English version of the scale 
to ensure that all questions were properly translated and to check the translation quality. Afterwards, a pilot study was carried out on 90 Egyptian students and 60 Saudi students to check the clarity, comprehension and the interpretation of each item of the of the Arabic questionnaire form.

Data analysis: Data were coded, tabulated and analyzed using SPSS version 20 (Armonk, NY: IBM Corp.). Descriptive data was expressed as numbers and percentages, and the Chi-square $\left(\chi^{2}\right)$ test was applied to test the relationship between variables. Quantitative data was expressed as mean and standard deviation (Mean \pm SD), and MannWhitney (U) test was applied to compare medians for groups not normally distributed. Spearman correlation test was applied to test the relationship between quantitative variables. A p-value of $<0.05$ was considered as statistically significant.

Results: Table (1) shows that Saudi female students had, compared to Egyptian female students, significantly higher rates of having a mobile phone (100\% vs 96.5\%), owning smart phones ( $71.6 \%$ vs $38 \%)$, longer period (more than 3 years) of having a mobile phone $(88.8 \%$ vs $65.5 \%)$ and a significant difference in in the number of daily calls. The MPAI scores were significantly higher among Saudi students, with significantly longer time of daily internet use and more frequent internet use per week. According to YIAT scores, Saudi students showed a significant higher mean score $(42.93 \pm 14.71)$ compared to the Egyptian students $(39.85 \pm 11.22)$.

Regarding mobile phone addiction, Figure (1) shows a significant difference between the two groups, with $11.7 \%$ of Saudi students were classified as mobile addicts compared to $6.1 \%$ of the Egyptian students. Among Saudi students, the prevalence of PIU (5.8\%) and potential problematic internet use (36.1\%) were significantly higher compared to the Egyptian students (1.6\% and 34.5\% respectively). Table( 2) shows that (85.5\%) of mobile phone addicts owned a mobile phone for more than 3 years, a percent that was significantly higher than that for non-addicts (73.8\%). In the same time, a non-significant difference was found between mobile addicts and non-addicts according the duration of owning the mobile phone. Table (3) reveals that older students in the $3^{\text {rd }}$ grade showed significant higher rates of both mobile phone addiction and PIU compared to the $1^{\text {st }}$ and the $2^{\text {nd }}$ grades. Figure (2) shows a significant positive correlation between YIAT scores and MPAI scores. 


\section{Discussion:}

Mobile phone ownership: In the present study, all Saudi students reported owning a mobile phone compared to $96.5 \%$ of the Egyptian students. According to the United Nations Conference on Trade and Development (UNCTAD), there are 180 mobile phones for every 100 residents in Saudi Arabia. ${ }^{(12)}$ Similarly, the total number of mobile subscriptions in Saudi Arabia was about 51 million, which nearly doubles the number of the country population in $2013 .^{(11)}$ The percent of Egyptian students who own a mobile phone $(96.5 \%)$ is similar with results reported by an Italian (96\%) ${ }^{(25)}$, and an American study (96.7\%). ${ }^{(26)}$ it is are also going with the report of the Egyptian Ministry of Communications and Information Technology in 2013, where the number of Egyptian mobile phone users reached 92 million, which is nearly equal to the number of country population. ${ }^{(14)}$

Duration of having a mobile phone: This study showed that $88.8 \%$ of Saudi students owned a mobile phone for more than 3 years compared to $65.5 \%$ of Egyptian students, and $71.6 \%$ of them have smart phones compared to $38 \%$ of Egyptian students. This could be attributed to the better economic standard of Saudi Arabia, an oil-based economy, with a higher Gross National Income (GNI) per capita. $^{(27)}$ The Saudi students had higher number of daily calls compared to Egyptian students. This is in agreement with a study reported an extensive use of mobile phone by the Saudi population. ${ }^{(16)}$

Mobile addiction prevalence :A significant higher prevalence of mobile phone addiction and higher MPAI scores was found among Saudi students, however mobile phone addiction prevalence among all students was within the worldwide range $(0-38 \%)$ reported in a previous literature. ${ }^{(1)}$ The prevalence among Saudi students is in line with some European studies. ${ }^{(28)}$ However, a lower prevalence of $6.3 \%$ was reported by Italian study among adolescents ${ }^{(29)}$, while a higher prevalence of $16.4 \%$ was reported among same age group by a study in Taiwan. ${ }^{(3)}$ This observed diversity in mobile addiction prevalence in the mentioned studies could be attributed to the usage of different instruments, assessment tools, cut-offs, classification criteria, and the difference in the social and cultural contexts which makes the comparability of the findings difficult.

Regarding Egyptian students, the prevalence of mobile phone addiction is consistent with the previously mentioned Italian study $(6.3 \%) .{ }^{(30)}$ The observed higher 
prevalence of mobile addiction among Saudi students could be attributed to the high percent of Saudi students who own smart phones. Smart phones provide free messengers and social media applications that provide users with free chat when they can get Wi-Fi access. ${ }^{(29)}$ In addition, smart-phone owners call and text more than traditional mobile phone owners, which make them at a greater risk to develop addiction. ${ }^{(30)}$ This difference could also be explained by the significant higher number of calls reported by Saudi students compared to Egyptian students. This association was demonstrated in previous studies which showed higher rates of addiction among extensive users. ${ }^{(31)}$

Mobile addiction and students' grades/duration of mobile ownership: In the present study, higher rates of mobile phone addiction were found among students in the $3^{\text {rd }}$ grade. The same result was found in a study done on Taiwanese adolescents. ${ }^{(3)}$ This was explained by the tendency of older individuals to get acquainted with the new technology. ${ }^{(32)}$ A significantly higher percent of mobile phone addicts was found among students who owned a mobile phone for more than 3 years (Table 2). The same result was demonstrated in a previous study, where mobile phone addiction level was significantly higher among students who owned a mobile at the age of 13 and below compared with students whose age for first mobile phone use was 16 and above. ${ }^{(31)}$

PIU prevalence: Saudi students reported significantly longer duration of daily internet use, more frequent internet use per week, and higher prevalence of PIU and potential problematic internet use compared to Egyptian students. The prevalence of PIU among Saudi and Egyptian students lies within the reported prevalence from Western and Eastern societies. ${ }^{(6,10)}$

The Saudi result is consistent with results of previous Saudi study done in Riyadh city on secondary school students which showed a prevalence of $5.3 \% .{ }^{(17)}$ The prevalence of PIU among Egyptian students is consistent with that reported by previous studies ${ }^{(19,20)}$, and the international studies done on the same age group. ${ }^{(33)}$ However it is much lower than the prevalence observed in a recent Egyptian study done on older university students, where $13 \%$ of the participants had PIU. ${ }^{(34)}$

This high figure among university students was explained previously by the too much unstructured time the university students have, which makes them seek for companionship through using the internet to 
escape the university stress from studying and exams. ${ }^{(35)}$ The observed difference in internet addiction between Saudi and Egyptian students could be attributed to the difference in internet population penetration which was estimated to be $54 \%$ for Saudis compared to $44.1 \%$ for Egyptians. ${ }^{(36)}$

PIU and students grades: In this study, higher prevalence of PIU was found among the $3^{\text {rd }}$ grade students when compared to the younger grades, a result that was observed in other studies ${ }^{(37)}$, and was attributed to the tendency of older students to have greater developmental dynamics, such as a stronger need to develop a sense of identity, and more access to the internet. ${ }^{(38)}$ In the present study, a number of social and lifestyle differences between Saudi and Egyptian females could explain the significant higher prevalence of internet and mobile phone addiction among Saudi females. Of them is the Saudi Arabia reputation for being more restrictive of women's mobility and public activity due to the implementation of Islamic principles in the society. ${ }^{(39)}$ Therefore, Saudi females having more time to spend on computer , internet and screen activities ${ }^{(40)}$, a trend that have changed to spending more time on smart phones, or iPads. ${ }^{(41)}$
Another reason for this excessive use could be the low studying load on Saudi girls as the quality of education is lower for females than males, in addition to the less qualified teachers. ${ }^{(42)}$ Regarding Egyptian adolescents, studies have observed the engagement of Egyptian females in different patterns of leisure time activities and the lower level of internet use among them. ${ }^{(43)}$ In addition to the higher prevalence of physical activity compared to Saudi females. ${ }^{(4)}$ They also were found to spend more time watching TV and doing religious activities. ${ }^{(45)}$ This lower level of internet use among Egyptian females was observed in the population council's Survey of Young People in Egypt (SYPE), where $23 \%$ of Egyptian youth are internet users, only $5 \%$ of them were females. ${ }^{(14)}$

\section{Correlation between mobile and internet} addiction: The significant positive correlation found between YIAT scores and MPAI scores (Figure-2) was revealed from previous studies. ${ }^{(7)}$ This correlation was explained by increasing mobile access to the internet by teens with increasing the adoption of smart phones ${ }^{(46)}$, in addition to the extensive usage of social networking on 
smart-devices among teens due to the ability of continuous connection to the internet. ${ }^{(29)}$

Study limitations: This is a cross-sectional study where the causality and the direction of relationships cannot be determined. The usage of a self-reported questionnaire has the probability of recall bias. In addition, the rules of the educational authorities in KSA prevent female researchers from conducting studies on male students. That is why the researchers assessed the prevalence of the two studied problems among female students only.

Conclusion: The aim of the present study was to compare the prevalence of problematic mobile phone and internet use between Egyptian and Saudi adolescent females. Based on the results of this study, a significant higher prevalence of both mobile and internet addiction was found among Saudi students who had more intensive use of mobile and internet. A significant positive correlation was also found between YIAT scores and MPAI scores. Based on the results of this study, an appropriate health educational program directed to adolescents about the proper use of the mobile phone and internet, and the adverse health consequences of their excessive use should be carried out in both countries. These programs can benefit from these communication channels to deliver health and healthy lifestyles messages to those young people and the whole family. Conflict of interest : None declared Acknowledgments: The author gratefully acknowledges the support provided by headmasters of schools in both countries, and from Dr Reda Abdellatif the lecturer of public health and community medicine, who helped in data collection from the Egyptian students.

\section{References:}

1. Pedrero-Pe'rez EJ, Rodrı'guez-Monje MT, Ruiz Sa'nchez De Leo'n JM. Mobile phone abuse or addiction: A review of the literature. Adicciones. 2012; 24:139152.

2. Suss D. Impacts of computer- and media usage on the personality development of children and young people. Ther Umsch. 2007; 64(2):103-118.

3. Yang YS, Yen JY, Ko CH, Cheng CP, Yen $\mathrm{CF}$. The association between problematic cellular phone use and risky behaviors and low self-esteem among Taiwanese adolescents. BMC Public Health. 2010; 10: 217- 224.

4. Fortunati L, Katz JE, Riccini R. Mediating the human body: Technology, communication and fashion. In: Fortunati 
L, Katz JE, Riccini R, editors. Manwah (New Jersey): Lawrence Erlbaum. Chapter 8, Mobile phone tribes: Youth and social identity; 2003. p. 87-92.

5. Gergen K, Harper R, Höflich J, Katz J, Meyrowitz J, Poster M. Mobile Democracy: Essays on Society, Self, and Politics. In: Nyíri K, editor. Vienna (Austria): Passagen Verla. Chapter 16, Virtual strangers: Young love and texting in the Filipino archipelago of cyberspace; 2003. p. $225-235$

6. Yen JY, Ko CH, Yen CF, Wu HY \& Yang MJ. The comorbid psychiatric symptoms of Internet addiction: attention deficit and hyperactivity disorder (ADHD), depression, social phobia, and hostility. J Adolesc Health. 2007; 41: 93-98

7. Chiu SI, Hong FY, Chiu SL. An Analysis on the Correlation and Gender Difference between College Students' Internet Addiction and Mobile Phone Addiction in Taiwan. International scholarly research notices. 2013; 2013: 110.file://C:/Users/M.salah/Downloads/3 $60607 \% 20$ (2).pdf

8. Ha JH, Chin B, Park DH, Ryu SH, Yu J. Characteristics of excessive cellular phone use in Korean adolescents. Cyber
Psychology \& Behavior. 2008; 11(6), 783-784.

9. Akin A, İskender M. Internet addiction and depression, anxiety and stress. International Online Journal of Educational Sciences. 2011;3(1):138-148

10. Jang KS, Hwang SY, Choi JY. Internet addiction and psychiatric symptoms among Korean adolescents. J Sch Health. 2008; 78(3): 165-171.

11. Communication and information technology commission: Version 17 / Issue: Safar 1435 H. Dec. 2013 www.citc.gov.sa

12. A report by the United Nations Conference on Trade and Development (UNCTAD).

http://english.alarabiya.net/articles/2012/ 03/11/200000.html

13. United Nations Development Programme (UNDP) \& Institute of National Planning (INP) (2010). Egypt Human Development Report 2010: Youth in Egypt: Building our Future. http://www.undp.org.eg/Portals/english.p df

14. Arab Republic of Egypt: Ministry of Communications and Information Technology: Egypt ICT Sector Indicators in brief: August 2013. www.mcit.gov.eg 
15. Khan MM. Adverse effects of excessive mobile phone use. Int J Occup Med Environ Health. 2008; 21(4): 289293.

16. Al-Khlaiwi T, Meo SA. Association of mobile phone radiation with fatigue, headache, dizziness, tension and sleep disturbance in Saudi population. Saudi Med J. 2004; 25(6): 732-736.

17. Al-hantoushi $\mathrm{MN}, \mathrm{Al}$-abdullateef $\mathrm{SH}$. Internet addiction among secondary school students in Riyadh city, its prevalence, correlates and relation to depression: A questionnaire survey. International Journal of Medical Science and Public Health. 2014; 3(1): 10-15.

18. Salama OE, Abou EL, Naga RM. Cellular phones: are they harmful?. J Egypt Publ Health Assoc. 2004; 79: 197-123.

19. Kamal NN, Mosallem FA. Determinants of Problematic Internet Use Among ElMinia High School Students, Egypt. Int J Prev Med. 2013; 4(12): 1429-1437.

20. Reda M, Rabie M, Mohsen N, Hassan A. Problematic Internet Users and Psychiatric Morbidity in a Sample of Egyptian Adolescents. Psychol. 2012; 3(8): 626-631.
21. Hawi N. Arabic validation of the Internet Addiction Test. Cyberpsychol Behav Soc Netw. 2013; 16 (3): 200-204.

22. Dimitri A, Christakis MMM, Jelenchick L, Mon T, Chuan- Zhou M. Problematic internet usage in US college students: a pilot study. BMC Med. 2011;9:77-82.

23. Wang H, Zhou X, Lu C, Wu J, Deng X, Hong L. Problematic Internet use in high school students in Guangdong province, China. PloS One. 2011;6:e19660.

24. Leung L. Linking psychological attributes to addiction and improper use of the mobile phone among adolescents in Hong Kong. J Child Media. 2008; 2(2): 93-113.

25. Dimonte M, Ricchiuto G. Mobile phone and young people. A survey pilot study to explore the controversial aspects of a new social phenomenon. Minerva Pediatr. 2006; 58: 357-363.

26. Merlo LJ, Stone AM, Bibbey A. Measuring Problematic Mobile Phone Use: Development and Preliminary Psychometric Properties of the PUMP Scale. Hindawi Publishing Corporation. J Addict. 2013; 2013:1- 7.

27. Saudi Arabia Economy Profile 2014. http://www.indexmundi.com/saudi_arabi a/economy_profile.html 
28. Martinotti G, Villella C, La Torre G, Thiene DD, Nicola MD, Bria $\mathrm{P}$ et al. Problematic mobile phone use in adolescence: a cross-sectional study. J Public Health. 2011; 19: 545-551.

29. Al-Barashdi HS, Bouazza A, Jabr NH. Smartphone Addiction among Sultan Qaboos University Undergraduates. Journal of Social Sciences Research. 2014; 5(2): 723-740.

30. Matthews T, Pierce J, Tang J. No Smartphone Is An Island: The Impact Of Places, Situations And Other Devices On Smart Phone Use. IBM Research Report, 2009.

http://domino.research.ibm.com/library/c yberdig.nsf/papers/F5FD878B5B062AC A85257635004EC3F5/\$File/rj10452.pdf

31. Sahin S, Ozdemir K, Unsal A, Temiz N. Evaluation of mobile phone addiction level and sleep quality in university students. Pak J Med Sci. 2013; 29(4): 913-918

32. Kurniawan S. Older people and mobile phones: A multi-method investigation. Int J Human-Computer Studies. 2008; 66: 889-01

33. Kormas G, Critselis E, Janikian M, Kafetzis D, Tsitsika A. Risk factors and psychosocial characteristics of potential problematic and problematic internet use among adolescents: A cross-sectional study. BMC Public Health. 2011; 11: 595-602

34. Desouky DE, Ibrahem RA. Internet Addiction and Psychological Morbidity among Menoufia University Students, Egypt. Am J Pub H Research. 2015; 3(5): 192-198.

35. Young KS. Internet addiction: A new clinical phenom-enon and its consequences. Am Behav Sci. 2004; 48: 402-415.

36. International Telecommunications Union (Geneva). Percentage of Individuals using the Internet 2000-2012. 2013.

http://en.wikipedia.org/wiki/List_of_cou ntries_by_number_of_Internet_users

37. Wu X, Chen X, Han J, Meng H, Luo J, Nydegger L, Wu $\mathrm{H}$. Prevalence and Factors of Addictive Internet Use among Adolescents in Wuhan, China: Interactions of Parental Relationship with Age and Hyperactivity-Impulsivity. PLoS One. 2013; 8(4): e61782

38. Daniel TL, Shek LY. Internet Addiction Phenomenon in Early Adolescents in Hong Kong. Scientific World Journal. 2012; 2012:1-9. 
file://C:/Users/M.salah/Downloads/1043

04\%20(1).pdf

doi:10.1100/2012/104304

39. Alsaleh S. Gender Inequality in Saudi Arabia: Myth and Reality. Department of Health Informatics, School of Public Health \& Health Informatics, King Saud bin Abdulaziz University for Health Sciences Riyadh, Saudi Arabia. P: 123130. http://www.ipedr.com/vol39/025ICITE2012-K00003.pdf

40. Al-Hazzaa HM, Al-Nakeeb Y, Duncan MJ, Al-Sobayel HI, Abahussain NA, Abdulrahman O. Musaiger AO, Lyons M, Collins P, Nevill A. A Cross-Cultural Comparison of Health Behaviors between Saudi and British Adolescents Living in Urban Areas: Gender by Country Analyses . Int. J. Environ. Res. Public Health, 2013; 10: 6701-6720 41. Retrieved from: http://www.arabnews.com/mobiledevices-replace-watching-tv-amongkingdom\%E2\%80\%99s-families

42. Roula B. Gender-Segregated Education in Saudi Arabia: Its Impact on Social
Norms and the Saudi Labor Market. Educ Policy Anal Arch. 2004; 12(28): 1-12

43. Celedonia KL, Wilson ML, El Gammal HA, Hagras AM. Physical fighting among Egyptian adolescents: social and demographic correlates among a nationally representative sample. PeerJ. 2013; 1:e125

44. El-Gilany AH, Badawi K, El-Khawaga G, Awadalla N. Physical activity profile of students in Mansoura University, Egypt. EMHJ. 2011; 17(8): 694-702

45. Abdelfatah BG, Mohamed RT, Moawad SS, Alsouada R. Factors affecting leisure time distribution among different aspects of activities and the influences of this distribution. Cairo University, Faculty of economics and political science, Department statistics. 2013 http://www.feps.edu.eg/en/departments/st atistics/2012/4.pdf

46. Madden M, Lenhart A, Duggan M, Cortesi S, Gasser U. Teens and Technology 2013. Pew Internet \& American Life Project, Berkman Center for Internet \& Society, Harvard's University 2013. 
Table (1): Distribution of the studied students regarding their characters, pattern of mobile phone, internet use and scores on YIAT and MPAI

\begin{tabular}{|c|c|c|c|c|c|c|}
\hline \multirow[t]{2}{*}{ Parameter } & \multicolumn{2}{|c|}{$\begin{array}{l}\text { Egyptian } \\
\text { Students } \\
\end{array}$} & \multicolumn{2}{|c|}{$\begin{array}{c}\text { Saudi } \\
\text { Students } \\
\end{array}$} & \multirow[t]{2}{*}{ Test } & \multirow[t]{2}{*}{ P-value } \\
\hline & No. & $\%$ & No. & $\%$ & & \\
\hline $\begin{array}{c}\text { Grad } \\
\text { - } 1^{\text {st }} \text { grade } \\
\text { - } 2^{\text {nd }} \text { grade } \\
\text { - } 3^{\text {rd }} \text { grade } \\
\end{array}$ & $\begin{array}{l}269 \\
256 \\
277 \\
\end{array}$ & $\begin{array}{l}33.5 \\
31.9 \\
34.5\end{array}$ & $\begin{array}{l}167 \\
184 \\
187 \\
\end{array}$ & $\begin{array}{c}31 \\
34.2 \\
34.8 \\
\end{array}$ & $\begin{array}{l}(\chi 2) \text { test } \\
1.13\end{array}$ & 0.567 \\
\hline $\begin{array}{l}\text { School type } \\
\text { - Public } \\
\text { - } \quad \text { Private } \\
\end{array}$ & $\begin{array}{l}537 \\
256\end{array}$ & $\begin{array}{l}67 \\
33\end{array}$ & $\begin{array}{l}294 \\
244\end{array}$ & $\begin{array}{l}54.6 \\
45.4\end{array}$ & $\begin{array}{c}(\chi 2) \text { test } \\
20.71\end{array}$ & $<0.001$ \\
\hline $\begin{array}{l}\text { Mean } \pm \text { SD of students age (Years) } \\
(17 \pm 1.03 \text { years })\end{array}$ & \multicolumn{2}{|c|}{$17.04 \pm 1.07$} & \multicolumn{2}{|c|}{$16.96 \pm 0.97$} & $\begin{array}{c}\text { U test } \\
196445\end{array}$ & 0.079 \\
\hline $\begin{array}{l}\text { Having a mobile phone } \\
\text { - Yes } \\
\text { - No }\end{array}$ & $\begin{array}{l}774 \\
28\end{array}$ & $\begin{array}{c}96.5 \\
3.5\end{array}$ & $\begin{array}{c}538 \\
0\end{array}$ & $\begin{array}{l}100 \\
0.00\end{array}$ & $\begin{array}{l}(\chi 2) \text { test } \\
19.18\end{array}$ & $<0.001$ \\
\hline $\begin{array}{l}\text { Duration of having a mobile phone } \\
\text { - Less than } 3 \text { years } \\
\text { - More than } 3 \text { years } \\
\end{array}$ & $\begin{array}{l}271 \\
503 \\
\end{array}$ & $\begin{array}{l}35 \\
65\end{array}$ & $\begin{array}{c}60 \\
478 \\
\end{array}$ & $\begin{array}{l}11.2 \\
88.8\end{array}$ & $\begin{array}{c}\left(\chi^{2}\right) \text { test } \\
95.79\end{array}$ & $<0.001$ \\
\hline $\begin{array}{l}\text { Type of mobile phone } \\
\text { - Usual phone } \\
\text { - Smart phone }\end{array}$ & $\begin{array}{l}480 \\
294\end{array}$ & $\begin{array}{l}62 \\
38\end{array}$ & $\begin{array}{l}153 \\
385\end{array}$ & $\begin{array}{l}28.4 \\
71.6\end{array}$ & $\begin{array}{l}(\chi 2) \text { test } \\
134.3\end{array}$ & $<0.001$ \\
\hline Number of calls daily & \multicolumn{2}{|c|}{$1.8 \pm 0.84$} & \multicolumn{2}{|c|}{$2.63 \pm 1.05$} & $\begin{array}{c}Z \text { test } \\
15.216\end{array}$ & $<0.001$ \\
\hline MPAI scores & \multicolumn{2}{|c|}{$38.83 \pm 8.018$} & \multicolumn{2}{|c|}{$40.25 \pm 8.015$} & $\begin{array}{l}\mathrm{Z} \text { test } \\
2.738\end{array}$ & 0.006 \\
\hline $\begin{aligned} \text { Time spent on-line per day } \\
\text { - }<2 \mathrm{~h} \\
\text { - } 2-\mathrm{h} \\
\text { - } \geq 4 \mathrm{~h} \\
\end{aligned}$ & $\begin{array}{c}618 \\
164 \\
19 \\
\end{array}$ & $\begin{array}{c}77.2 \\
20.5 \\
2.4 \\
\end{array}$ & $\begin{array}{c}377 \\
138 \\
23 \\
\end{array}$ & $\begin{array}{c}70.1 \\
25.6 \\
4.3 \\
\end{array}$ & $\begin{array}{l}(\chi 2) \text { test } \\
9.71\end{array}$ & 0.008 \\
\hline $\begin{aligned} \text { Frequency of internet use per week } \\
\begin{aligned} \text { - } & <3 \text { times } \\
\text { - } & 3-6 \text { times } \\
\text {. } & >6\end{aligned} \\
\end{aligned}$ & $\begin{array}{l}186 \\
136 \\
479 \\
\end{array}$ & $\begin{array}{c}23.2 \\
1759.8\end{array}$ & $\begin{array}{c}97 \\
84 \\
357 \\
\end{array}$ & $\begin{array}{c}18 \\
15.6 \\
66.4 \\
\end{array}$ & $\begin{array}{l}(\chi 2) \text { test } \\
6.68\end{array}$ & 0.035 \\
\hline YIAT scores & \multicolumn{2}{|c|}{$39.85 \pm 11.22$} & \multicolumn{2}{|c|}{$42.93 \pm 14.71$} & $\begin{array}{c}\text { U test } \\
200498\end{array}$ & 0.028 \\
\hline
\end{tabular}

NB. $1^{\text {st }}$ grade is 16 year-olds, $2^{\text {nd }} 17$ year-olds and $3^{\text {rd }}$ grade is of 18 year-olds. 
Table (2): Relationship between mobile addiction and duration of owning a mobile phone

\begin{tabular}{|c|c|c|c|c|c|c|}
\hline \multirow{3}{*}{ Parameter } & \multicolumn{4}{|c|}{$\begin{array}{l}\text { Duration of owning a mobile } \\
\text { phone }\end{array}$} & \multirow{3}{*}{$(\chi 2)$ test } & \multirow{3}{*}{ p-value } \\
\hline & \multicolumn{2}{|c|}{$<3$ years } & \multicolumn{2}{|c|}{$\geq 3$ years } & & \\
\hline & No. & $\%$ & No. & $\%$ & & \\
\hline $\begin{array}{c}\text { Mobile phone addiction } \\
-\quad \text { Non-addict } \\
-\quad \text { Addict }\end{array}$ & $\begin{array}{c}315 \\
16\end{array}$ & $\begin{array}{l}26.2 \\
14.5\end{array}$ & $\begin{array}{c}887 \\
94\end{array}$ & $\begin{array}{l}73.8 \\
85.5\end{array}$ & 7.26 & 0.007 \\
\hline $\begin{array}{ll}\text { Internet addiction } \\
- & \text { Non-addict } \\
- & \text { Potential addict } \\
- & \text { Addict }\end{array}$ & $\begin{array}{c}219 \\
104 \\
8\end{array}$ & $\begin{array}{l}27.2 \\
22.4 \\
18.6\end{array}$ & $\begin{array}{c}585 \\
361 \\
35\end{array}$ & $\begin{array}{l}72.8 \\
77.6 \\
81.4\end{array}$ & 4.74 & 0.093 \\
\hline
\end{tabular}


Table (3): Relationship between internet and mobile phone addiction and student's grades

\begin{tabular}{|c|c|c|c|c|c|c|c|c|}
\hline \multirow{3}{*}{ Parameter } & \multicolumn{6}{|c|}{ Students' grades } & \multirow{3}{*}{$\left(\chi^{2}\right)$ test } & \multirow{3}{*}{ p-value } \\
\hline & \multicolumn{2}{|c|}{$1^{\text {st }}$ grade } & \multicolumn{2}{|c|}{$2^{\text {nd }}$ grade } & \multicolumn{2}{|c|}{$3^{\text {rd }}$ grade } & & \\
\hline & No. & $\%$ & No. & $\%$ & No. & $\%$ & & \\
\hline $\begin{array}{l}\text { Mobile phone addiction } \\
\text { - Non-addict } \\
\text { - Addict }\end{array}$ & $\begin{array}{c}408 \\
18\end{array}$ & $\begin{array}{l}33.9 \\
16.4\end{array}$ & $\begin{array}{c}386 \\
41\end{array}$ & $\begin{array}{l}32.1 \\
37.3\end{array}$ & $\begin{array}{c}408 \\
51\end{array}$ & $\begin{array}{l}33.9 \\
46.4\end{array}$ & 14.86 & 0.001 \\
\hline $\begin{array}{l}\text { Internet addiction } \\
\text { - Non-addict } \\
\text { - Potential addict } \\
\text { - } \text { Addict }\end{array}$ & $\begin{array}{c}318 \\
115 \\
3\end{array}$ & $\begin{array}{c}38.5 \\
24.2 \\
6.8\end{array}$ & $\begin{array}{c}272 \\
254 \\
14\end{array}$ & $\begin{array}{c}33 \\
32.7 \\
31.8\end{array}$ & $\begin{array}{c}23520 \\
2 \\
27\end{array}$ & $\begin{array}{l}28.5 \\
42.9 \\
61.4\end{array}$ & 55.02 & $<0.001$ \\
\hline
\end{tabular}




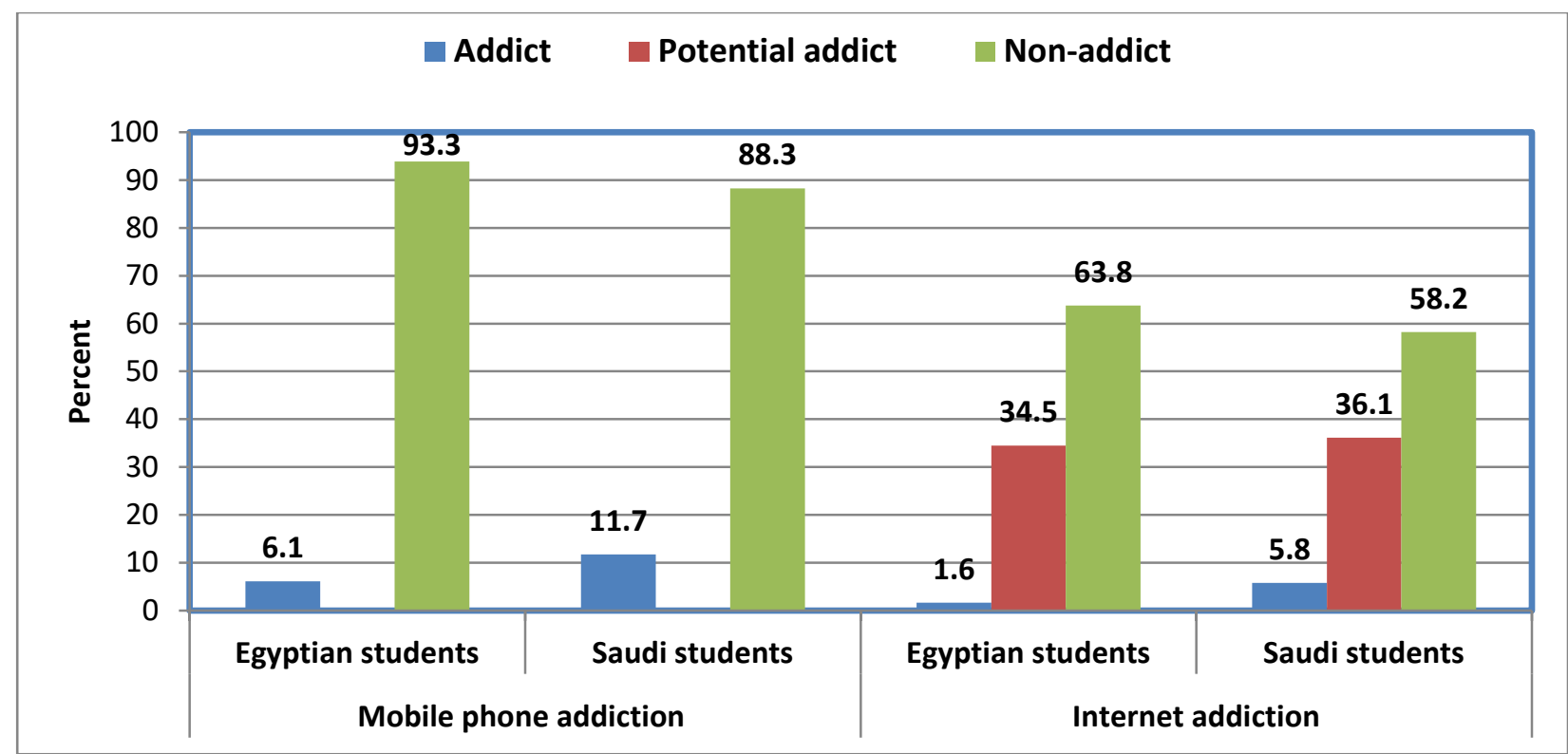

Figure (1): Distribution of students regarding mobile phone and internet addiction

NB: For mobile phone addiction: $(\chi 2=13.13 \& \mathrm{P}$ value $<0.001)$

NB: For internet addiction: $(\chi 2=18.70 \& \mathrm{P}$ value $<0.001)$

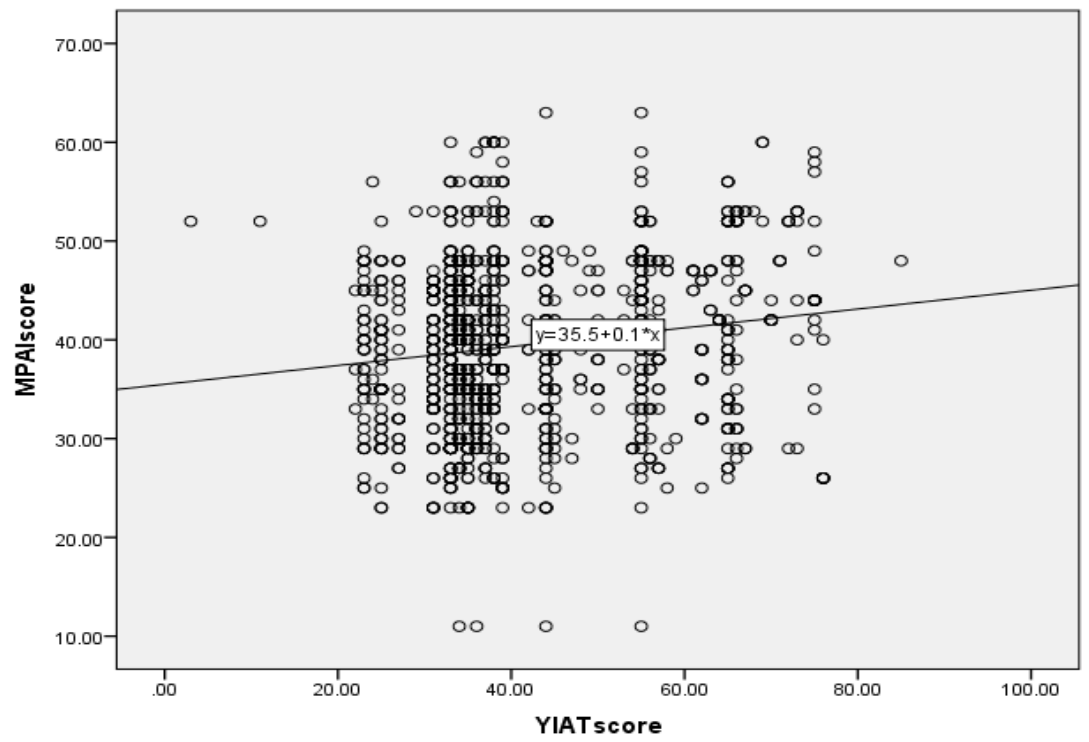

Figure (2): Scatter plot of YIAT scores against MPAI scores
NB: Correlation coefficient: 0.127
Correlation is significant at p-value: $<0.001$ 


\section{الملخص العربي}

إثكالية استخدام الهاتف المحمول والإنترنت: دراسة مقارنة بين المراهقات السعوديات والمصريات

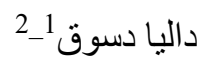

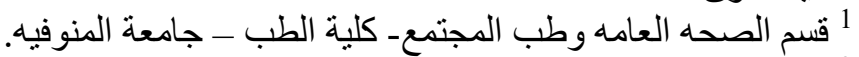

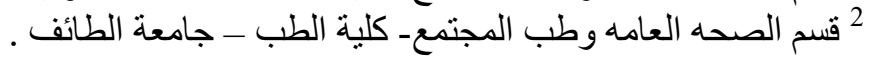

الخلفية: المراهقون هم الفئة الاكثر تعرضا للإدمان على الهاتف المحمول والإنترنت , وتعد الدراسات حول كلا النوعين من الإدمان في الدول العربية نادرة. الأهداف: هدفت هذه الدراسة إلى مقارنة مدى انتشار ادمان الإنترنت والهاتف المحمول بين المراهقات المصريات والسعوديات. المنهجية وطرق البحث : تم إجراء دراسة مقطعية على 538 طالبة سعودية و 802 طالبة مصرية. و قام المشاركون بملء استبيانات حول أنماط استخدام الهاتف المحمول والإنترنت , و تم استخدام اختبار إدمان الإنترنت للشباب و مقياس إدمان الهاتف المحمول. النتائج: أظهر الطلاب السعوديون معدلات أعلى للإدمان على الهاتف المحمول والإنترنت (11.7\% , 5.8\%) مقارنة بـ (6.1\% و 1.6\%) للطلاب المصريين. كما أظهروا عددًا أكبر من المكالمات ووقتًا أطول لاستخدام الإنترنت واستخدامًا أكثر تكرارية للإنترنت في الأسبوع. وقد وجدت علاقة طردية ذات دلالة احصائية بين درجات كل من مقياسى اختبار إدمان الإنترنت للشباب و مقياس إدمان الهاتف المحمول. الحخلاصة: خلصت هذه الدراسة إلى الحاجة إلى دراسات مستقبلية لمعالجة عوامل الخطر ذات الصلة لكلتا المشكلتين بين المراهقين في كلا البلدين. 